1989

\title{
The Use of Written Transcripts in Powerful and Powerless Language Research
}

Larry Vinson

McNeese State University

Craig E. Johnson

George Fox University, cjohnson@georgefox.edu

Follow this and additional works at: http://digitalcommons.georgefox.edu/gfsb

Part of the Business Commons

\section{Recommended Citation}

Vinson, Larry and Johnson, Craig E., "The Use of Written Transcripts in Powerful and Powerless Language Research" (1989). Faculty Publications School of Business. Paper 27.

http://digitalcommons.georgefox.edu/gfsb/27 


\title{
The Use of Written Transcripts in Powerful and Powerless Language Research
}

\author{
LARRY YINSON and CRAIG JOHNSON*
}

This study tested the salience of hesitations and hedges in a simulated student government situation. suhkces reported more hesitations in writing but noted more hedges on tape. Award amounts were significantly higher when powerless testimony was delivered orally rather than in writing. $N_{1}$ ) similar effect was found for credibility ratings. Implications of these findings in light of the "hammer effect" are discussed.

In the past decade a number of researchers from communication and other fields have identified forms of speech that they have labeled as "powerful" or "powerless." These forms of specech get their labels from the impressions they generate for reakers. Powerful talk establishes perceptions of dominance for speakers while powerless speech creates impressions of tentativeness and submissiveness (Johnson, 1987). In general, the use of such powerless speech features as hesitation forms ("uh," "ah"), hedges ("I think," "I guess"), tag questions ("It's a nice (lay, isn't it?") and disclaimers ("Don't get me wrong, but") lewers the credibility and effectiveness of speakers (Erickson, l.ind, Johneon \& ()'Barr, 10) 8 ; (conkey, O'Barr \& Lind, 1978; Lind \& ('Barr. 19)- Bradley, 1981; Bradac \& Mulac, 1984a; 1984b). Powerless speech in mout detracting w speakers when they seek to be authoritative rather than sociable (Bradac \& Mulac, 19) 4 ta)

Rexcarchers examining the impact of powerful and powerless language have relied heavily on the use of written transcripts to investigate what is ural in nature (Erickson et al., 19)78: Bradac, Hemphill \& Tardy, 1981; ()'Barr, 1982: Bradac \& Mulac, 1984a). Powerless language investigators defend their decision to utilize written transcripts by noting that written and oral channels generate the same pattern of findings (O'Barr, 1982, p. ()+). According to Bradac and Mulac (1984a), "Previous studies of powerful and powerless styles have consistently obtained virtually identical outcomes for judgments of communicator characteristics across written and spoken presentations" (p. 317).

While previous studies reveal that oral and written presentations generate the same pattern of findings, some doubt remains as to the relative salience of powerless language forms in the spoken vs. the written mode. For example, even though they contend that findings are constant across delivery channels, Bradac and Mulac (1984a) speculate that differences in

\footnotetext{
- Larry Vinson is Asustant Professor of Communication and Theater at McNeese State University, Craig Johnson is Assistant Professor of Communication and Literature at George Fox College.

The authors wish to thank Tom Hardin and Tom Pecora for their assistance in gathering data for this project.
} 
perceived power between individual forms of talk may be smaller when such features are delivered orally. They note that confounding paralinguistic variables exist in speech and that receivers do not monitor speech as closely as they do the written word (p. 317). The question of whether or not powerless speech features are more salient in writing than in speaking takes on added significance in light of the "hammer effect" postulated by Bell, Zahn and Hopper (1984). Bell and associates argue that unrealistically high frequencies of powerless speech features account for significant findings in many studies. They claim that many researchers "hammer" subjects with large numbers of powerless speech forms in short transcripts. As a result, respondents give lower evaluations to powerless sources. These investigators suggest that powerless language forms are more apparent in written transcripts since both visual and paralinguistic distractions are eliminated (p. 35). If so, then the use of written transcripts heightens the "hammer effect" since the impact of powerless talk is magnified in writing.

The purpose of this study was to determine if powerless language features are more salient when written than when spoken. One method of investigating the impact of powerless speech features across presentation modes is to ask auditors to estimate how many powerless speech features they perceive when reading or hearing the same material. If powerless features are more salient when written, then readers should report the presence of greater amounts of such talk. Therefore, the following hypothesis was tested:

Hypothesis 1: Readers will perceive more powerless language features than will listeners.

A second way to test the saliency of powerless language features is to compare response to the speaker and message between delivery channels. If powerless language is more salient in writing, then the powerless written condition might generate significantly lower evaluations than the powerless spoken condition and have significantly less persuasive impact. However, as noted earlier, previous data indicates that the pattern of effects is the same across channels (Erickson et al., 1978; O'Barr, 1982; Bradac \& Mulac, 1984a). Because an argument could be developed for both positions, a research question was deemed most appropriate:

Question 1: Will the oral version of a powerless message generate significantly higher credibility ratings and award amounts than the written version?

\section{METHOD}

\section{Subjects and Procedures}

Ninety college students and 90 high school students from the Midwest served as subjects. Eighty-seven were female and 93 were male.

Stimulus materials were centered around a simulated budget allocation case used in prior research (Johnson \& Vinson, 1987). In this case, a representative of a student organization called the Negotiation Club 
delivers testimony before the Student Senate. Subjects were asked to serve as student schattors and to ketermine an allocation for the Negotiation Club from the student senatc budget. Testimony was delivered in either a powerful (straightforward) or powerless manner in writing or on tape. The powcrless rersion contained hesitation forms ("uh," "um," "well," "you know") and hedges ("I think," "I guess"). The frequency of powerless speceh features ( 1 for every 3.0 seconds of testimony) approximated that employed by Erickson and associates (1978) in their initial investigation of powerless and powerful speech styles. Transcripts for the spoken and written presentations were identical. No information on paralinguistic features was contained in the written version and hesitation forms were set off with commas ("We as an organization are, uh, willing to get involved in disputes here on campus"). Two female speakers recorded the ural testimony. When pretests for the previous study Johnson \& Vinson, $14 \mathrm{~S}^{-}$) revealed no important differences in response to the speakers based ()n paralinguistic variables, only one witness was employed in that inrestigation and in this one.

\section{Measurement}

Witness credibility was measured through the use of competence and character items from the McCroskey credibility instrument (1981) and dynamism items from the Berlo, Lemert and Mertz credibility scale (1969). In addition, subjects were asked to make an allocation for the Negotiation (Juh on a range of $\$() t() \$ 5,(0)()$ and to estimate how many of each puwerlen feature they had heard or read in the testimony on a scale from (1) (1) 10() .

\section{Data Andlyis and I) cign}

The experiment was a 2 (powerful and powerless testimony) $\mathrm{x} 2$ (oral and writcen (hannel) factorial design. The reliability of credibility factors was mearured through the computation of alpha scores. Hypotheses were tested through analyses of variance and Newman Keuls tests (alpha .05). Puwer, set at .81 ) with a 35 effect size, required a per cell $N$ of 20 (Cohen, $\left.1)^{--}\right)$.

\section{RESULTS}

Reliability Seores

Preliminary analyses generated the following alpha scores: (a) competence (.92), (b) character (.74), and (c) dynamism (.90). The mean scores (1) itcms comprising each dimension were averaged and used as dependent variables in subsequent analyses.

\section{Manipulation Check}

To check the effect of the power manipulation, main effects for each dependent measure were generated. As expected, the powerful speaker received higher competence $(\mathrm{F}(1,178)=276, p<.0001)$, character 
$(\mathrm{F}(1,178)=109, \mathrm{p}<.0001)$ and dynamism ratings $(\mathrm{F}(1,178)=14 x, f)<$ .0001 ) than the powerless witness (see Table 1). In adclition, the straightforward source received higher award amounts in response to her testimony $(\mathrm{F}(1,178)=69, p<.0001)$. The pattern of results was the same for speech style on both channels. However, spoken testimony generated higher competence $(\mathrm{F}(1,174)=10.9, p<.001)$ and character $(\mathrm{F}(1,174)=9.3, p<$ .003) evaluations than the written testimony (see Table 1 ).

TABLE 1

Means and Standard Deviations for Main Effects

\begin{tabular}{|c|c|c|c|c|c|c|c|c|c|}
\hline & \multicolumn{2}{|c|}{ Oral } & \multicolumn{2}{|c|}{ Written } & \multicolumn{2}{|c|}{ Powerful } & \multicolumn{2}{|c|}{ Powerless } & \multirow[t]{2}{*}{$E t a^{2}$} \\
\hline & $\bar{X}$ & (SD) & $\bar{x}$ & (SD) & $\overline{\mathrm{X}}$ & (SD) & $\bar{X}$ & $(S D)$ & \\
\hline Award & 1850 & $(1++2)$ & 159() & $(1012)$ & $\cdot 2555$ & $(1+9)(0)$ & 963 & $(1107)$ & $27.7 \%$ \\
\hline Competence & $=5.4^{\circ}$ & $(2.42)$ & 4.07 & $(2.31)$ & $* 7.03$ & $(1.20)$ & 3.32 & $(1.77)$ & $02.0 \%$ \\
\hline Character & .0 .04 & $(1.48)$ & 5.47 & $(1 .+(0)$ & 0.72 & $(1.02)$ & +89 & $(1.33)$ & $40.0 \%$ \\
\hline Dynamism & 4.37 & $(2.16)$ & 4.23 & $(2.14)$ & $* 5.81$ & $(1.77)$ & 2.92 & $(1.40)$ & $45.4 \%$ \\
\hline Hesitations & $\cdot 22.80$ & $(23.2)$ & 29.12 & $(24.8)$ & ${ }^{*} 8.02$ & $(8.8 .3)$ & 42.1 & $(220)$ & $51.6 \%$ \\
\hline Hedges & $=2+.08$ & $(23.4)$ & 210 & $(10.3)$ & $\cdot 12.6$ & $(15.5)$ & 32.8 & $(19.5)$ & $25,3 \%$ \\
\hline
\end{tabular}

- significant main effects

Hypothesis 1

Hypothesis 1 was partially supported. While readers perceived more hesitations $(\mathrm{F}(2,172)=4.0, p<.05)$, listeners noted more hedges $(\mathrm{F}(2,173)$ $=5.5, p<.01$ ) (see Tables $1 \& 2$ ). Hesitation forms were more salient in writing but hedges garnered more attention when presented orally.

\section{Research Question}

The research question focused on whether or not the powerless oral presentation would generate significantly higher credibility ratings and award amounts than the powerless written presentation. No substantive differences in credibility ratings for the powerless source were noted across delivery modes. However, a significant channel by speech style interaction effect was noted for the award dependent measure (see Table 2). That is, award amounts were significantly higher when powerless testimony was delivered orally rather than in writing $(\mathrm{F}(2,173)=6.4, p<.01)$. In this instance, the powerless witness was less effective in writing than when speaking. A regression analysis was done to determine if hesitations or hedges accounted for the greatest amount of variance in subject response to the powerless source. Of the two forms, hesitations were the most significant (see Table 3). ${ }^{.}$Since hesitation forms were the most damaging powerless feature and more hesitations were noted in writing, this may account for the lower award amounts in the powerless written treatment. 
TABLE 2

Means, Standard Deviations and Contrasts for Significant Interactions

\begin{tabular}{|c|c|c|c|c|c|c|c|c|c|}
\hline \multirow[b]{3}{*}{ Award } & \multicolumn{2}{|c|}{$\begin{array}{l}\text { Written } \\
\text { (1) }\end{array}$} & \multicolumn{2}{|c|}{$\begin{array}{l}\text { ()ral } \\
(2)\end{array}$} & \multicolumn{2}{|c|}{$\begin{array}{l}\text { Written } \\
\text { (3) }\end{array}$} & \multicolumn{2}{|c|}{$\begin{array}{l}\text { Oral } \\
(4)\end{array}$} & \multirow[b]{2}{*}{ Contrasts } \\
\hline & $\bar{x}$ & $(S I)$ & $\bar{x}$ & $(S I))$ & $\bar{x}$ & $(S I))$ & $\bar{x}$ & $(\mathrm{SD})$ & \\
\hline & 2712 & $(1051)$ & $2+15$ & $(13+6)$ & 011 & (()৪8) & $13(04)$ & $(1330)$ & $2=1>4>$ \\
\hline Hesitations & 832 & (1) 27 ) & $7-70$ & $(x .51)$ & +7.2 & $(19.1)$ & 37.2 & $(23.7)$ & $2=1<4<$ \\
\hline Hedger & $1+.3$ & $(10.0)$ & 11.1 & $(1+.5)$ & 27.9 & $(13.3)$ & 37.0 & $(23.2)$ & $2=1<3<$ \\
\hline
\end{tabular}

TABLE 3

Regression Equations for Hesitations and Hedges on the Dependent Measures

\begin{tabular}{|c|c|c|c|c|c|c|c|c|}
\hline \multirow[b]{3}{*}{ Award } & \multicolumn{4}{|c|}{ Hestations } & \multicolumn{4}{|c|}{ Hedges } \\
\hline & $F(d f)$ & $p$ & $r^{2}$ & B & $F(d f)$ & $p$ & $r^{2}$ & B \\
\hline & $5(x 1.18(1)$ &.$(1)(1)(1) 1$ & 2384 &.-+8 & $\mathrm{NIE}^{*}$ & & & \\
\hline (impetence & $14^{(1)}(1,18(1)$ &.$(1)(1)(1) 1$ & +5.41 & $-.0^{7}$ & NIE ${ }^{*}$ & & & \\
\hline Chardeter & $10(x) 1,180)$ & $00(0) 1$ & $3-118$ & $-(0)$ & $\mathrm{NIE}^{*}$ & & & \\
\hline I)ynumism & (1) $3(1,18(1))$ & $(m)(0) 1$ & $3+(10)$ & -.58 & $51(2,170)$ & .00001 & 2.3 & -.18 \\
\hline
\end{tabular}

- vir taled anenter equatum

\section{DISTESTSION}

The results of this study raise some interesting issues regarding the relative effect of oral is written powerless messages. On the one hand, subjects noted more hesitations in writing and hesitation forms, in turn, had the greatcit negative impact on evaluations of the powerless witness. On the other hand. fewer hedges were noted in writing. It may be that different forms of powerless talk are processed in different ways. Some forms may be more salient in writing, others more salient in speech. Thus, the molecular approach (Bradac \& Mulac, 1984a) should be followed when itudying across channel effects. Individual forms of powerless language should be tented separately to measure salience between delivery modes.

some support was found in this investigation for the argument that the use of written transcripts heightens the "hammer effect" described by Bell et al. (1984). Higher subject awareness of written hesitations suggests that the use of transcripts increases the "hammer effect." However, lower awareness of written hedges may contradict this notion. The only significant difference in response to the powerless witness between delivery modes emerged on the award outcome variable. Placing powerless speech in the written transcript reduced the persuasiveness, but not the credibility, of the witness. Apparently, the presence of high numbers of 
hesitations (the most damaging powerless feature in this study) in eithcr writing or speaking is enough to generate negative impressions. Future research should determine the attributional consequences of using morc moderate (and perhaps more typical) levels of hesitations and other powerless language forms across delivery channels.

\section{NOTES}

1. Differences in the number of hedges (26) and hesitations (40) used in the transcript for this study make direct power comparisons between the two impossible. However, these results suggest that hesitations are less powerful than hedges as Bradac and Mulac (1984) contend. Hosman and Wright (1987), on the other hand, suggest that interactions between hedges and hesitations forms produce effects that "raise some uncertainty" (p. 183) about the language hierarchy proposed by Bradac and Mulac.

\section{REFERENCES}

Bell, R., Zahn, C., \& Hopper, R. (1984). Disclaiming: A test of two competing views. Communication Quarterly, 32. 28-36.

Berlo, D., Lemert, J., \& Mertz, R. (1969). Dimensions for evaluating the acceptability of message sources. Public Opinion Quarterly, 33, 563-576.

Bradac, J., Hemphill, M., \& Tardy, C. (1981). Language style on trial: Effects of "powerful" and "powerless" speech upon judgments of victims and villains. Western Journal of Speech Communication, 45, 327-341.

Bradac, J., \& Mulac, A. (1984a). A molecular view of powerful and powerless speech styles: Attributional consequences of specific language features and communicator intentions. Communication Monographs, 51, 307-319.

(1984b). Attributional consequences of powerful and powerless speech styles in a crisis-intervention context. Journal of Language and Social Psychology, 3. 1-19.

Bradley, P. (1981). The folk-linguistics of women's speech: An empirical examination. Communication Monographs, 48, 73-90.

Cohen, J. (1977). Statistical power analysis for the behat'ioral sciences. New York: Academic Press.

Conley, J., O'Barr, W., \& Lind, E. (1978). The power of language: Presentational style in the courtroom. Duke Law Journal, 1375-1399.

Erickson, B., Lind, E., Johnson, B., \& O'Barr, W. (1978). Speech style and impression formation in a court setting: The effects of "powerful" and "powerless" speech. Journal of Experimental Social Psychology, 14, 266-279.

Hosman, L., \& Wright, J. (1987). The effects of hedges and hesitations on impression formation in a simulated courtroom context. Western Journal of Speech Communication, $5 l$, 173-188.

Johnson, C. (1987). An introduction to powerful and powerless talk in the classroom. Communication Education, 36, 167-172.

Johnson, C., \& Vinson, L. (1987). "Damned if you do, damned if you don't?": Status, powerful speech and evaluations of female witnesses. Women's Studies in Communication, 10 , $37-44$.

Lind, E., \& O'Barr, W. (1979). The social significance of speech in the courtroom. In H. Giles and R. St. Clair (Eds.), Language and Social Psychology (pp. 66-87). College Park, Md: University of Maryland Press.

McCroskey, J., \& Young, T. (1981). Ethos and credibility: The construct and its measurement after three decades. Central States Speech Journal, 32, 24-34.

O'Barr, W. (1982). Linguistic evidence: Language, power and strategy in the courtroom. New York: Academic Press. 